\title{
Immunostimulating Effects of Polysaccharides of Panax ginseng by Oral Administration into BALB/c Mice
}

\author{
Mi-Hyeon Kang ${ }^{1, \S}$, A-Young Park ${ }^{1, \S}$, Ae-Hee Yang ${ }^{2, \$}$, Ye-Eun Park ${ }^{1}$, \\ Seung-Hye Hong ${ }^{1}$, Gab-Soon Park ${ }^{3}$ and Suk-Yul Jung ${ }^{1, \uparrow}$ \\ ${ }^{I}$ Department of Biomedical Laboratory Science, Molecular Diagnostics Research Institute, \\ Namseoul University, Choongnam 331-707, Korea \\ ${ }^{2}$ Health Bio Med Institute for Life Science, Health BioMed, Seoul 135-857, Korea \\ ${ }^{3}$ Department of Business, Health BioMed, Seoul 135-857, Korea
}

\begin{abstract}
Ginsan, polysaccharide isolated from the root of Panax ginseng C.A. Meyer, has been shown to be a potent immunomodulator, producing several cytokines and stimulating lymphoid cells to proliferate. In this study, ginsan was orally inoculated into BALB/c mice up to 39 days and the activity of immune cells containing macrophages and T cells was analyzed. Moreover, the production of cytokines, e.g., tumor necrotic factor- $\alpha$ (TNF- $\alpha$ ), interferon- $\gamma$ (IFN- $\gamma$ ), GM-CSF and IL-12 was also analyzed. In results, the phagocytosis of macrophages was increased. About $13 \%$ cytotoxicity of NK cells was observed in 22 days and 29 days of administration. But, oral administration did not highly affect the proliferation of T cells. In cytokine analysis, $150 \mathrm{mg} / \mathrm{kg}$ and $300 \mathrm{mg} / \mathrm{kg}$ at 22 days and 29 days showed three times more increase in TNF- $\alpha$ than the controls. IFN- $\gamma$ showed 1.07 and 1.16 times more increase at $150 \mathrm{mg} / \mathrm{kg}$ and $300 \mathrm{mg} / \mathrm{kg}$ over 22 days, respectively more than the controls. 32 days of $150 \mathrm{mg} / \mathrm{kg}$ and $300 \mathrm{mg} / \mathrm{kg}$ induced GM-CSF of about 1.3 times more than the controls. IL-12 was not induced in samples more than the controls. Ginsan could be a potential immunostimulator. Therefore, our study suggests that it can be adapted as an immunostimulator that requires a relatively short oral administration.
\end{abstract}

Key Words: Panax ginseng, Ginsan, Macrophage, NK cell, Cytokine

\section{INTRODUCTION}

The root of Panax ginseng C.A. Meyer (Araliaceae) has been one of the most popular natural tonics used in Asian countries. Ginsan, polysaccharide isolated from the root of Panax ginseng C.A. Meyer, has been shown to be a potent

*Received: September 8, 2014 / Revised: September 26, 2014

Accepted: September 27, 2014

${ }^{\S}$ Mi-Hyeon Kang, A-Young Park and Ae-Hee Yang contributed equally to this work.

${ }^{\dagger}$ Corresponding author: Suk-Yul Jung. Department of Biomedical Laboratory Science, Molecular Diagnostics Research Institute, Namseoul University, 91 Daehak-ro, Seonghwan-eup, Seobuk-gu, Cheonan-city, Choongnam 331-707, Korea.

Tel: +82-41-580-2723, Fax: +82-41-580-2932

e-mail: syjung@nsu.ac.kr

CThe Korean Society for Biomedical Laboratory Sciences. All rights reserved. immunomodulator, producing several cytokines (TNF- $\alpha$, IL-1 $\beta$, IL-2, IL-6, IL-12, IFN- $\gamma$, GM-CSF) and stimulating lymphoid cells to proliferate (Shin et al., 2002; Song et al., 2002; Song et al., 2003). It was reported that ginsan was capable of stimulating immune effector cells such as T cells, cytotoxic T lymphocytes (CTL), and natural killer (NK) cells (Song et al., 2002). Pretreatment of mice with ginsan protected them from lethal effects of ionizing radiation $($ DMF for radiation-induced lethality $=1.45$ ) (Ivanova et al., 2006). In addition, it has been proposed that cytokines produced from splenocytes could be involved in the generation of cytotoxic cells by ginsan (Yun et al., 1998). In addition, ginsan possesses marked radioprotective and antiseptic properties (Lim et al., 2002; Song et al., 2003). The water extracts of ginseng showed antitumor activity against 
certain kinds of tumor cells in mice (Lee et al., 1971) and inhibited the incidence of lung tumors by carcinogens (Yun et al., 1983). Effects of the ginsan polysaccharides of Panax ginseng have been elucidated for the production of cytokines and stimulation of immune cells. However, it has not yet been reported that oral administration of ginsan into mice would have stimulating effects on BALB/c mice. In this study, ginsan was orally inoculated into BALB/c mice up to 39 days and the activity of immune cells containing macrophages and $\mathrm{T}$ cells were analyzed. Moreover, the production of cytokines, e.g., tumor necrotic factor- $\alpha$ (TNF- $\alpha$ ), interferon- $\gamma$ (IFN- $\gamma$ ), GM-CSF and IL-12 was also analyzed.

\section{MATERIALS AND METHODS}

\section{Extraction of polysaccharides of Panax ginseng and their administrations into $\mathrm{BALB} / \mathrm{c}$ mice}

To extract polysaccharides of Panax ginseng C.A. Meyer, 4 to 8 volumes of water were added to its roots, and then the oncoming mixture was extracted at $75^{\circ} \mathrm{C}$ to $80^{\circ} \mathrm{C}$ for 36 to 72 hours. This process was repeated three times. The extracts were filtered with a $0.22 \mu \mathrm{m}$-sized filter and slowly cooled. The chilled extracts were filtered again with the filter above and concentrated at $60^{\circ} \mathrm{C}$ in a vacuum. The concentrated extracts were mixed with absolute ethanol and were precipitated in a cold condition until polysaccharides were completely precipitated. A layer of saponin was then removed. The resulting polysaccharides were dissolved with water and were concentrated in a vacuum. They were maintained in a cold condition for over 2 weeks and the remaining enzymes were inactivated. The final stabilized polysaccharides were autoclaved and freeze-dried. This prepared powder of Panax ginseng C.A. Meyer was provided by healthbiomed Co. Ltd.. For their oral administration into 6-week female BALB/c mice (Nara biotech, Korea), 150 $\mathrm{mg} / \mathrm{kg}$ and $300 \mathrm{mg} / \mathrm{kg}$ were prepared and the administration was performed daily up to 39 days. All experiments to use animals were approved by Namseoul Animal Committee (No. NSU-14-06)

\section{Phagocytosis assay of macrophages using Escherichia coli}

Macrophages were isolated from peritoneal exudate cells as described by Klimetzek and Remold (Klimetzek et al., 1980). Thioglycollate-elicited peritoneal exudate cells were obtained from BALB/c mice following intraperitoneal injection of $1 \mathrm{~mL}$ thioglycollate and lavage of the peritoneal cavity with $5 \mathrm{~mL}$ of medium after 4 days. Peritoneal exudate cells were seeded at densities of $1 \times 10^{5}$ cells/well into a 96-well cell culture plate. After 24 hour incubation, unattached cells were removed and adherent cells were used for the association assay. To analyze phagocytic ability of macrophage, association assays were applied because macrophages possess similar effects with Acanthamoeba (Jung et al., 2007). Briefly, macrophages were cultured in 96-well plates in RPMI 1640. Once confluent, the unbound macrophages were aspirated and bound macrophages were washed once with phosphate-buffered saline (PBS). Macrophages were incubated with Escherichia coli $\left(2 \times 10^{6} \mathrm{cfu} /\right.$ well/0.5 mL of PBS) and plates incubated for up to $1 \mathrm{hr}$ at room temperature. Following this incubation, macrophages were washed with PBS three times to remove non-associated bacteria and macrophage counted using a haemocytometer. Finally, macrophage were lysed by adding sodium dodecyl sulfate (SDS) (0.5\% final concentration) to each well for $30 \mathrm{~min}$ and the numbers of macrophage were enumerated by plating on LB agar plated as previously described (Alsam et al., 2006). The percentage of macrophage association was calculated as follows: recovered $E$. coli (cfu)/total $E$. coli $(\mathrm{cfu}) \times 100=\%$ E. coli associated with macrophage. In addition, the ratio of bacteria to macrophage was calculated as follows: recovered $E$. coli $(\mathrm{cfu}) /$ number of macrophage $=E$. coli $/$ macrophage ratio.

\section{Activity of natural killer (NK) cells using YAC-1 cell}

Spleen was isolated from BALB/c mice; and the spleen cells, by grinding using slide glasses were washed with RPMI 1640 media containing fetal bovine serum, 2 mmol/1 glutamine and $100 \mathrm{mg} / \mathrm{l}$ penicillin-streptomycin. They were inoculated with $1 \times 10^{5}$ cells/well into 96-well cell culture plates. YAC-1 as a target cell against natural killer (NK) 
cell was added to the plates of spleen cells at a ratio of 1:5 (Yoo et al., 2014). The co-incubation was maintained at $37^{\circ} \mathrm{C}$ for $5 \mathrm{hr}$ and lactate dehydrogenase assay (LDH) were performed to analyze cytotoxicity of NK cells (Jeong SR et al., 2005). Briefly, $50 \mu \mathrm{L}$ of reacted supernatant in each well was transferred to a 96-well assay plate. After addition of $50 \mu \mathrm{L}$ of reconstituted assay buffer from a Cyto-Tox96 Non-radioactive Cytotoxicity Assay kit (Promega, Madison, $\mathrm{WI}$ ), the plate was incubated for $30 \mathrm{~min}$ at RT, and then 50 $\mu \mathrm{L}$ of stop solution was added. The reactants were read at $490 \mathrm{~nm}$ using an enzyme-linked immunosorbent assay reader. The formula used to calculate the percent in vitro cytotoxicity was as follows: (sample value - control value) $/($ total LDH release - control value $) \times 100$.

\section{T cell proliferation assay}

To analyze $\mathrm{T}$ cell proliferation by polysaccharides of Panax ginseng, T cells were isolated from mice spleens by columns (R\&D systems). Briefly, single cell suspensions of murine leukocytes were depleted of erythrocytes by use of a hypotonic lysing reagent. Processed cells that were to be loaded onto the column were resuspended in $1 \mathrm{~mL}$ of 1 $\times$ column wash buffer. The top cap of the column was removed first to avoid drawing air into the bottom of the column. Next, the bottom cap was removed. After the column buffer had drained down to the level of the white filter, the $1 \mathrm{~mL}$ cell suspension was applied to the top of the column. The cells were incubated at room temperature for $10 \mathrm{~min}$. After the incubation step, T cells were eluted from the column with 4 aliquots. The collected T cells are centrifuged at $250 \times \mathrm{g}$ for $5 \mathrm{~min}$. T cells $\left(1.5 \times 10^{5}\right.$ cells well) were inoculated into a 96-well cell culture plate. After 4 days, $10 \mu \mathrm{L}$ of CCK-8 solutions were added to the plate. Next $5 \mathrm{hr}$ incubation was done and absorbance was measured at $450 \mathrm{~nm}$ using a microplate reader.

\section{Measurement of cytokines}

To analyze whether polysaccharides of Panax ginseng stimulated immune cells, cytokines, e.g., tumor necrotic factor- $\alpha$ (TNF- $\alpha$; R\&D systems), interferon- $\gamma$ (IFN- $\gamma$; Koma biotech), GM-CSF (Koma biotech), IL-12 (Koma biotech) were measured. Briefly, $100 \mu \mathrm{L}$ of mice sera or standards were added to an assay plate and washed. $100 \mu \mathrm{L}$ of the detection antibody was added and streptavidin-horseradish

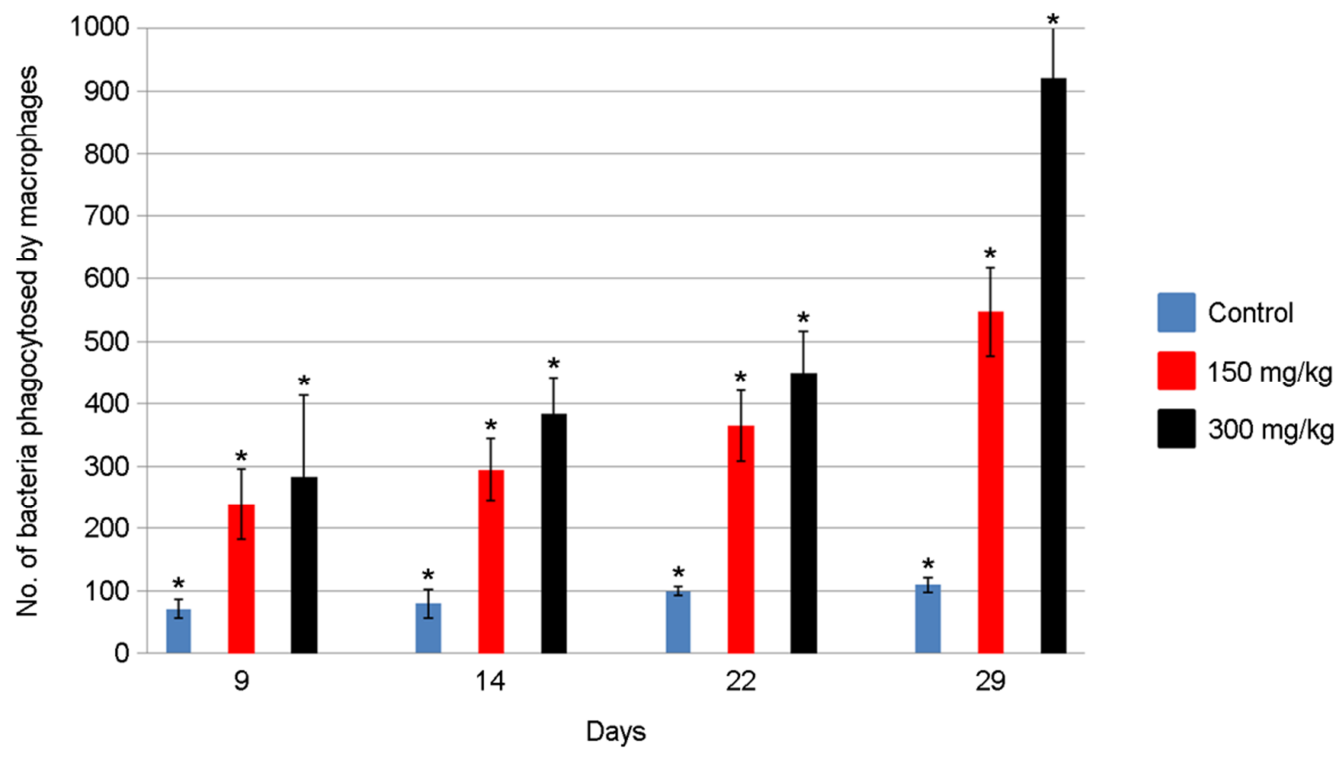

Fig. 1. Phagocytosis of macrophages in BALB/c mice by oral administration of ginsan. It was analyzed up to 29 days. Phagocytosis of the macrophages was analyzed using their bacteria uptake by counting colony forming unit (CFU). Results are presented as the mean \pm standard deviations of three independent experiments performed in triplicate. Asterisks indicate a significant difference, i.e., $P<0.05$, using paired T-test, one-tail distribution. 


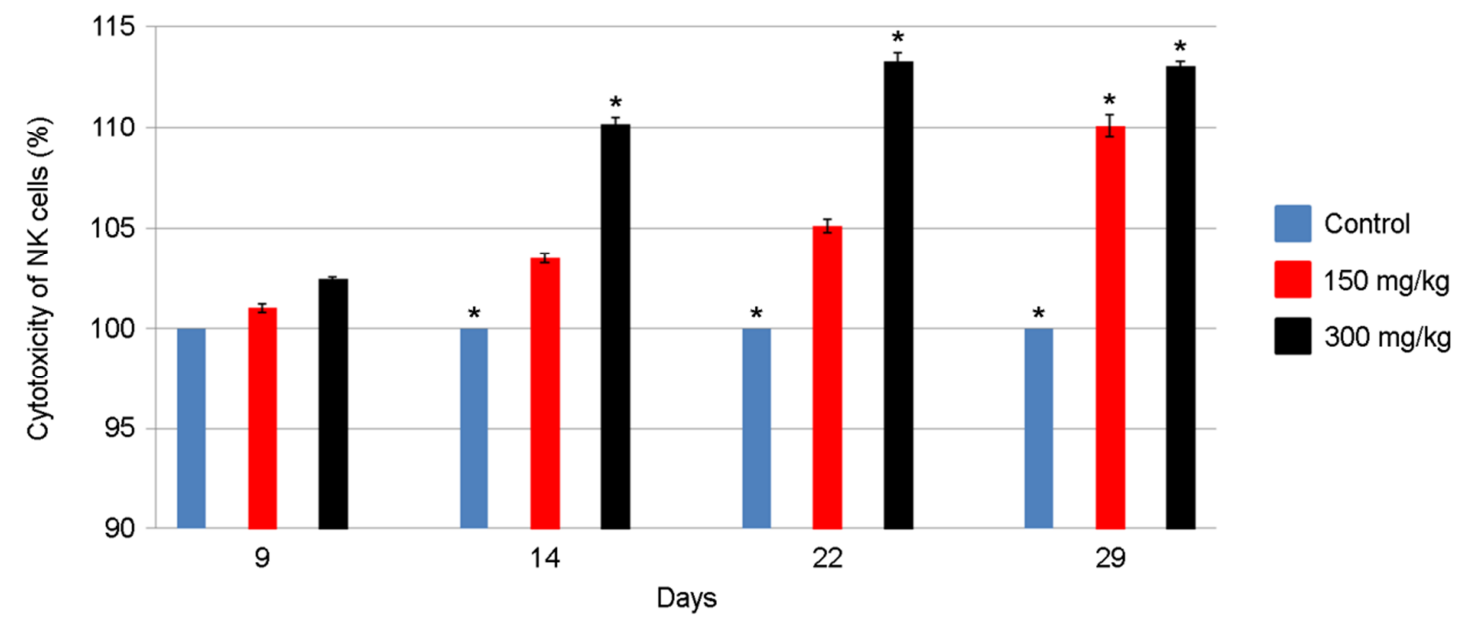

Fig. 2. Cytotoxicity of NK cells isolated from mice spleens. It was analyzed up to 29 days. $150 \mathrm{mg} / \mathrm{kg}$ and $300 \mathrm{mg} / \mathrm{kg}$ was compared with controls of saline-inoculated mice. Results are presented as the mean \pm standard deviations of three independent experiments performed in triplicate. Asterisks indicate a significant difference, i.e., $P<0.05$, using paired T-test, one-tail distribution.

peroxidase (HRP) to each well. Finally, substrate and stop solution were applied and absorbance was measured at 450 $\mathrm{nm}$.

\section{RESULTS}

\section{Phagocytosis of macrophages to $E$. coli}

To understand the immunostimulating effects of ginsan, the phagocytosis of macrophages was analyzed. Using a bacterium of non-pathogenic E. coli, the procedures were performed and they were modified as compared with a previous report (Jung et al., 2007). Overall, there was 2 to 3 times more increase in the phagocytosis of macrophages from $150 \mathrm{mg} / \mathrm{kg}$ and $300 \mathrm{mg} / \mathrm{kg}$ than the controls of only saline-administration (Fig. 1). For longer administration, phagocytosis seemed to be higher but ratios compared with controls and samples were similar. Asterisks indicated a significant difference showing $P<0.05$. It suggested that ginsan would increase the phagocytosis of macrophages by oral administrations.

\section{Cytotoxicity of NK cells against YAC-1}

About $5 \%$ of the spleen is made up of NK cells. For the activity of NK cells, YAC-1 cell have been used as a target cell. Here, to understand the effect of ginsan, the cyto- toxicity of NK cells was analyzed using YAC-1 cell. When initial analysis of NK cell-cytotoxicity in 9-day administration was performed, there was a little increase in its cytotoxicity (Fig. 2). And about $13 \%$ cytotoxicity was observed in 22 days and 29 days of administration. Asterisks indicated a significant difference showing $P<0.05$. Taken together, it suggested that ginsan would increase the cytotoxicity of NK cells isolated from BALB/c spleen by oral administrations.

\section{Proliferation of $\mathbf{T}$ cells by oral administration of ginsan}

As shown in figure 1 and 2, ginsan would stimulate immune cells such as NK cell and macrophage. To understand whether ginsan induced $\mathrm{T}$ cell proliferation, $\mathrm{T}$ cells were isolated from mice spleens and their numbers were analyzed by a biochemical assay (Fig. 3). As compared with the controls of only saline-inoculated mice, $150 \mathrm{mg}$ / $\mathrm{kg}$ and $300 \mathrm{mg} / \mathrm{kg}$ did not show higher proliferations of $\mathrm{T}$ cells. Our results showed that oral administration did not have significant effect on the proliferation of $\mathrm{T}$ cells.

\section{Production of cytokines}

Previous reports showed that ginsan stimulated immune cells and induced the production of several cytokines. It was not well understood that oral administration of ginsan 


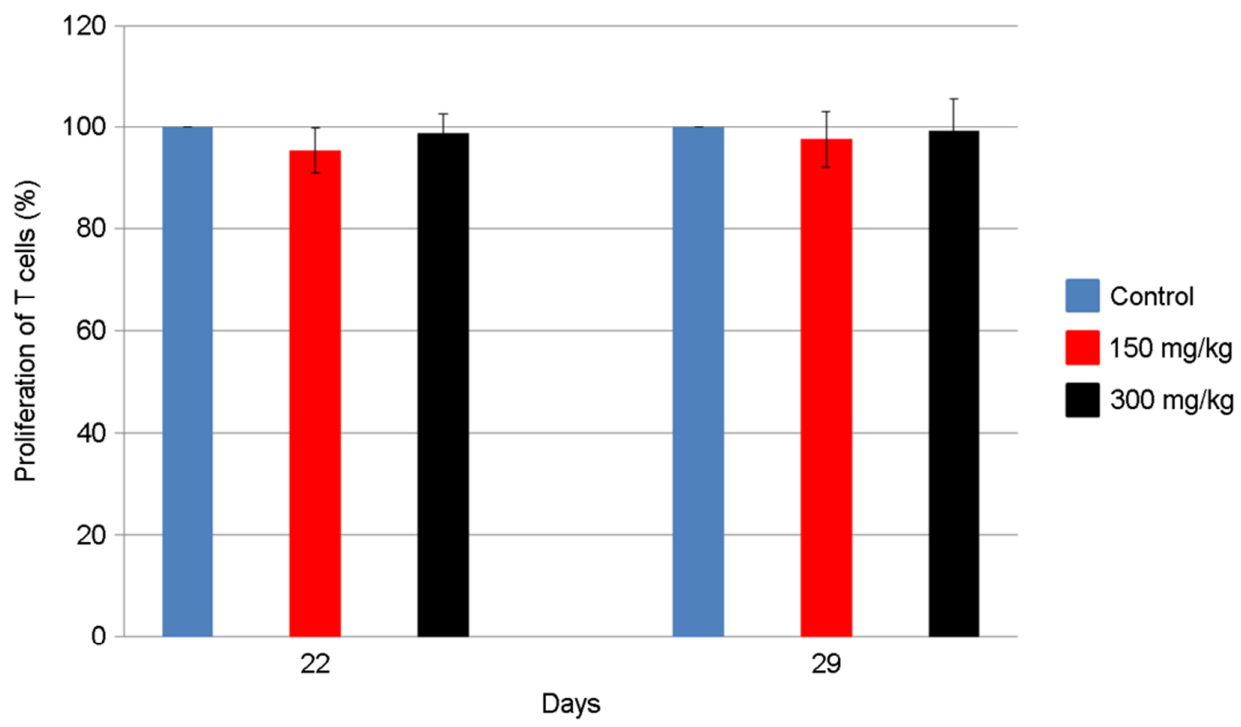

Fig. 3. Proliferation of T cell isolated from mice spleens. After $\mathrm{T}$ cells were isolated, they were incubated at $37^{\circ} \mathrm{C}$ under $5 \% \mathrm{CO}_{2}$ for 4 days and analyzed by a biochemical assay using a CCK-8 kit.
A

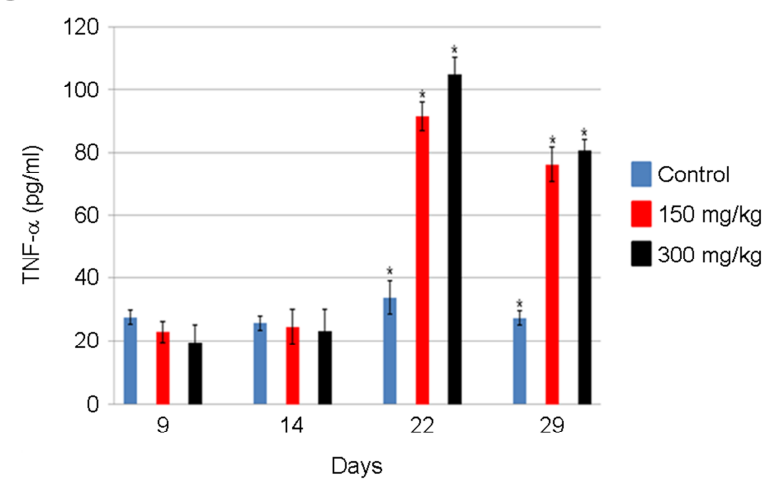

C

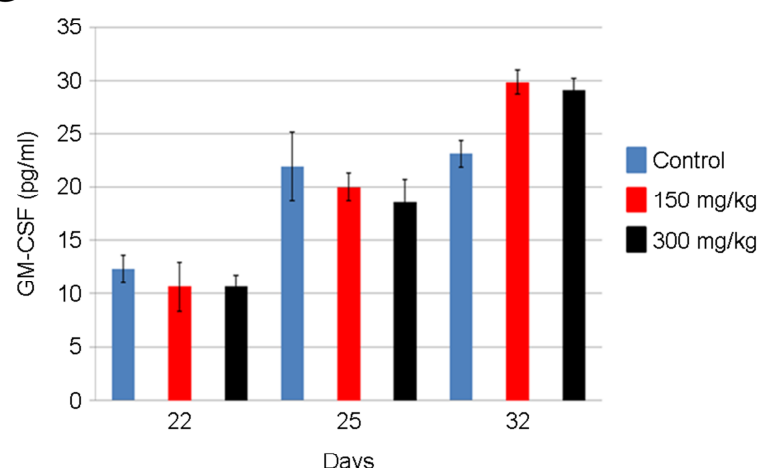

B

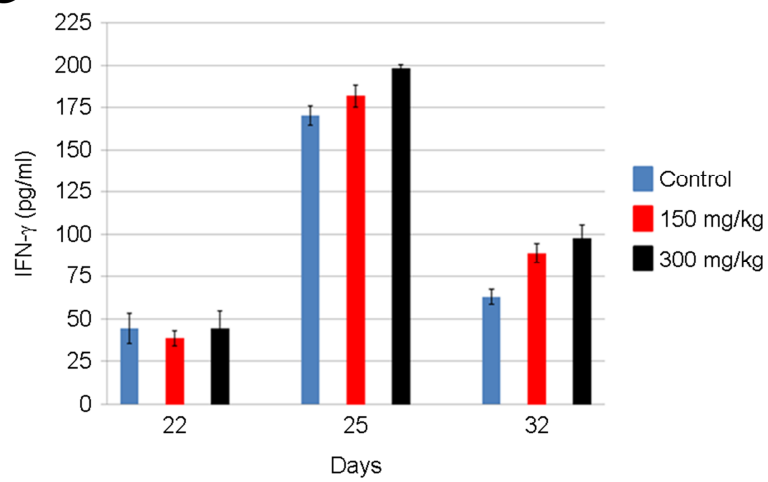

(D)

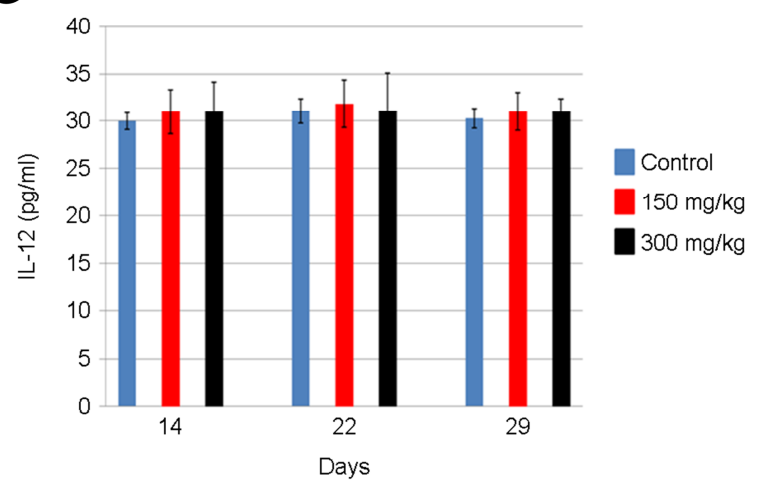

Fig. 4. Production of cytokines by oral administration of ginsan. TNF- $\alpha$, INF- $\gamma$, GM-CSF and II - 12 were analyzed up to 32 days. They are indicated with amount of $\mathrm{pg} / \mathrm{mL}$ rather than absorbance. Results are presented as the mean \pm standard deviations of three independent experiments performed in triplicate. Asterisks indicate a significant difference, i.e., $P<0.05$, using paired T-test, one-tail distribution. 
induced the production of cytokines in BALB/c mice. Ginsan could stimulate immune cells such as NK cell and macrophage as shown in figures. It implied that ginsan induced the production of cytokines. TNF- $\alpha$ was measured until 29 days of oral administration in BALB/c. It was not increased at 9 and 14 day analysis but $150 \mathrm{mg} / \mathrm{kg}$ and 300 $\mathrm{mg} / \mathrm{kg}$ at 22 and 29 days showed three times more increase than the controls (Fig. 4A). INF- $\gamma$ showed the increase 1.07 and 1.16 times of $150 \mathrm{mg} / \mathrm{kg}$ and $300 \mathrm{mg} / \mathrm{kg}$ at 22 days, respectively more than the controls (Fig. 4B). Twenty nine days of $150 \mathrm{mg} / \mathrm{kg}$ and $300 \mathrm{mg} / \mathrm{kg}$ induced 1.4 and 1.56 times more than the controls (Fig. 4B). GM-CSF showed similar patterns with INF- $\gamma$. Interestingly, 32 days of 150 $\mathrm{mg} / \mathrm{kg}$ and $300 \mathrm{mg} / \mathrm{kg}$ induced about 1.3 times more than the controls (Fig. 4C). IL-12 was not induced in samples more than the controls (Fig. 4D). Asterisks indicated a significant difference showing $P<0.05$. Taken together, ginsan induced TNF- $\alpha$, INF- $\gamma$ and GM-CSF but did not induce IL-12 by oral administration into BALB/c mice.

\section{DISCUSSION}

$P$. ginseng has been widely used in oriental medicine. Ginsan, a polysaccharide isolated from the root of Panax ginseng C.A. Meyer, is a potent immunomodulator that produces cytokines and stimulates lymphoid cells to proliferate (Shin et al., 2002; Song et al., 2002; Song et al., 2003). In the present study, ginsan could increase the phagocytosis of macrophages and cytotoxicity of NK cells but was not enough to proliferate $\mathrm{T}$ cells by oral administrations. It induced TNF- $\alpha$, INF- $\gamma$ and GM-CSF but did not induce IL-12 by oral administration into BALB/c mice. It was reported that ginsan could modulate mucosal immune response in asthma model (Lim et al., 2009) and bacterial infection ( $\mathrm{Na}$ et al., 2009). On hand, ginsan may serve as an efficient supplement for the oral vaccine because ginsan significantly increased both secretory and serum antibodies to orally administered antigens as ginsan enhanced antibody response to orally introduced antigens by modulating the COX expression in the Peyer's patches ( $\mathrm{Na}$ et al., 2010). Ginsan is a component of a natural product and it should not have any side effect. For example, it was reported that ginsan in the dose of $100 \mathrm{mg} / \mathrm{kg}$ did not alter serum ALT, AST, ALP activities, and total bilirubin and albumin levels indicating no hepatotoxic action of ginsan itself in mice (Song et al., 2004). Ginsan is a group of polysaccharides, suggesting that it can use saccharides-signaling pathway. The cell activation pathway of ginsan was similar to that of lipopolysaccharide (LPS) (Shin et al., 2002). Moreover, since ginsan does not have lipid moiety, such as lipid A, which bind to LPS-binding protein (LBP), it is likely that ginsan can activate macrophages by directly binding CD14 via LBP-independent pathway (Shin et al., 2002).

Taken together, this study suggested that ginsan would be a potential immunostimulator. Therefore, our study suggests that it can be adapted as an immunostimulator that requires a relatively short oral administration.

\section{Acknowledgements}

Funding for this paper was provided by healthbiomed CO. Ltd.

\section{REFERENCES}

Ahn JY, Kim MH, Lim MJ, Park S, Lee SL, Yun YS, Song JY. The inhibitory effect of ginsan on TGF- $\beta$ mediated fibrotic process. J Cell Physiol. 2011. 226: 1241-1247.

Ivanova T, Han Y, Son HJ, Yun YS, Song JY. Antimutagenic effect of polysaccharide ginsan extracted from Panax ginseng. Food Chem Toxicol. 2006. 44: 517-521.

Jeong SR, Lee SC, Song KJ, Park S, Kim K, Kwon MH, Im KI, Shin HJ. Expression of the $n f a 1$ gene cloned from pathogenic Naegleria fowleri in nonpathogenic $N$. gruberi enhances cytotoxicity against $\mathrm{CHO}$ target cells in vitro. Infect Immun. 2005. 73: 4098-4105.

Jung SY, Matin A, Kim KS, Khan NA. The capsule plays an important role in Escherichia coli $\mathrm{K} 1$ interactions with Acanthamoeba. Int J Parasitol. 2007. 37: 417-423.

Kim KH, Lee YS, Jung IS, Park SY, Chung HY, Lee IR, Yun YS. Acidic polysaccharide from Panax ginseng, ginsan, induces Th1 cell and macrophage cytokines and generates LAK cells in synergy with rIL-2. Planta Med. 1998. 64: 110-115.

Klimetzek V, Remold HG. The murine bone marrow macrophage, a sensitive indicator cell for murine migration inhibitory factor and a new method for their harvest. Cell Immunol. 1980. 53 
$257-266$.

Lee KD, Huemer RP. Antitumoral activity of Panax ginseng extracts. Jpn J Pharmacol. 1971. 21: 299-302.

Lee YS, Chung IS, Lee IR, Kim KH, Hong WS, Yun YS. Activation of multiple effector pathways of immune system by the antineoplastic immunostimulator acidic polysaccharide ginsan isolated from Panax ginseng. Anticancer Res. 1997. 17: 323 -331 .

Lim DS, Bae KG, Jung IS, Kim CH, Yun YS, Song JY. Antisepticaemic effect of polysaccharide from Panax ginseng by macrophage activation. J Infect. 2002. 45: 32-38.

Moon EY, Pyo S. Inhibition of various functions in murine peritoneal macrophages by aflatoxin $\mathrm{B} 1$ inhibits exposure in vivo. Int J Immunopharmaco. 1999. 21: 47-58.

Na HS, Lim YJ, Yun YS, Kweon MN, Lee HC. Ginsan enhances humoral antibody response to orally delivered antigen. Immune Netw. 2010. 10: 5-14.

Shin JY, Song JY, Yun YS, Yang HO, Rhee DK, Pyo S. Immunostimulating effects of acidic polysaccharides extract of Panax ginseng on macrophage function. Immunopharmacol Immunotoxicol. 2002. 24: 469-482.
Song JY, Akhalaia M, Platonov A, Kim HD, Jung IS, Han YS, Yun YS. Effects of polysaccharide ginsan from Panax ginseng on liver function. Arch Pharm Res. 2004. 27: 531-538.

Song JY, Han SK, Bae KG, Lim DS, Son SJ, Jung IS, Yi SY, Yun YS. Radioprotective effects of ginsan, an immunomodulator. Radiat Res. 2003. 159: 768-774.

Song JY, Han SK, Son EH, Pyo SN, Yun YS, Yi SY. Induction of secretory and tumoricidal activities in peritoneal macrophages by ginsan. Int Immunopharmacol. 2002. 2: 857-865.

Yoo SA, Kim OK, Nam DE, Kim Y, Baek H, Jun W, Lee J. Immunomodulatory effects of fermented Curcuma longa $\mathrm{L}$. extracts on RAW 264.7 cells. J Korean Soc Food Sci Nutr. 2014. 43: 216-223.

Yun YS, Kim KH, Lee YS, Jung IS, Park SY, Chung HY, Lee IR. Acidic polysaccharide from Panax ginseng, ginsan, induces Th1 cell and macrophage cytokines and generates LAK cells in synergy with rIL-2. Planta Med. 1998. 64: 110-115.

Yun TK, Yun YS, Han IW. Anticarcinogenic effect of long-term oral administration of red ginseng on newborn mice exposed to various chemical carcinogens. Cancer Detect Prev. 1983. 6: $515-525$. 